\title{
Job Satisfaction Amongst Accountants: The Case of Accounting Service Firms in Hanoi
}

\author{
Dr. Duc Tai Do* \\ University of Labor and Social Affairs, Vietnam \\ Dr. Dang Huy Nguyen \\ Hanoi University of Business and Technology, Vietnam \\ Dr. Thi Huong Nguyen \\ Faculty of Social work, University of Labor and Social Affairs, Vietnam \\ Dr. Hong Phong Vu \\ University of Labor and Social Affairs, Vietnam
}

\begin{abstract}
This study is conducted for measuring the job satisfaction amongst accountants in the accounting service firms in Hanoi. The study has also performed some descriptive analysis, Cronbach's Alpha and Independent T-test for evaluating and measuring the Job satisfaction amongst accountants. The results show that the Job satisfaction amongst accountants achieved an average of 3.683/5. The study does not find significant differences on evaluation of the Job satisfaction amongst accountants in terms of gender and age.
\end{abstract}

Keywords: Job satisfaction amongst, accountants, accounting service firms

JEL code: M41, O15

DOI: $10.7176 /$ RJFA/10-18-16

Publication date:September $30^{\text {th }} 2019$

\section{Introduction}

Smith (2007) argues that work plays a central role in people's lives, thus the level of satisfaction with the work is a critical component of the overall happiness of workers. The satisfaction level of employees is achieved when they feel satisfied with the opportunity for training, career advancement, consent to the supervision of their superiors and have a harmonious relationship with colleagues.

An organization with a healthy cultural environment, where the commitment between employees and the organization as well as the levels of employee satisfaction is high, avowedly increases the probability of success of an organization's strategic implementation programs (Le, 2016).

Accounting services firms have provided clients with a wide range of accounting services including: (i) Building structure of accounting apparatus and conduct accounting work for newly established businesses, building an internal accounting system to serve for administration; (ii) Reviewing, analyzing, reforming and rationalizing active accounting and financial apparatuses; (iii) Consulting to help businesses comply with regulations on document preparation, accounting document transfer, opening and recording of accounting books, cost collection and product cost calculation, review and adjustment of accounting data and closing entries, annual reports making, settlement reports of investment capital making, etc.

In the accounting service firms, human resource accounting is mainly, accounting human resource are responsible for all activities of the company. The development of the company, accounting human reource play the most important role, creating value for the goals set by the company. Ergo, one of the matters in need of our concern is whether the human resources, particularly the accounting personnel of these firms, are able to meet the job's requirements under new circumstances and to improve their performance in order to adapt to the rhythm and tendency of this country's socioeconomic development (Do et al. 2019a). Job satisfaction amongst accountants will contribute to improve the quality of accounting human resources? What solutions do accounting service firms need to improve job satisfaction amongst accountants?

\section{Literature Review}

There have been numerous studies on job satisfaction, notably: Andrew (2002), when studying job satisfaction in the United States and some other countries, he came up with components of job satisfaction, which include: training and promotions, colleagues, income, workplace, safety, travel time, supervision, and public relations. Crossman and Bassem (2003) stated that employee satisfaction included 7 components: job nature, training and promotion opportunities, leadership, colleagues, salaries, benefits and working environment. According to Luddy (2005), the components of job satisfaction include 7 components: job position, supervision of superiors, relationship with colleagues, job content, compensation and other rewards (promotions, material conditions of the 
working environment, organizational structure). Another study by Chawla (2009) in the telecom industry also mentioned employee satisfaction. The author pointed out 9 components to measure the employee satisfaction: safety level, nature of work, salary and income, working conditions, recognition of achievements, relationship with colleagues, job autonomy, leadership behaviors and promotion opportunities.

In Vietnam, Tran (2012), studied the satisfaction of Call Center employees and presented the components of a 10-scale measure: salary and promotion, meaningful work, monitoring mechanisms, relationship with colleagues, working conditions, training mechanisms, the nature of work, welfare and recognition of achievements. Luong (2015) studied the job satisfaction of workers in SOS Children's Village in Northern Vietnam pointed out that the components of the scale include: satisfaction with current job at the unit, satisfaction with working conditions at the unit, satisfaction with salary and benefits at the unit, satisfaction with training policies and promotion opportunities at the unit, satisfaction with employees' superiors, satisfaction with employees' colleagues. Do el at. (2018) studied the factors affecting the performance of accountants. Research results show that job satisfaction is one of 5 factors that positively affect the performance of the accountant. The authors said that job satisfaction included these things: I understand my job requirements, my workload is acceptable, my job is challenging and interesting, my work is closely related to many colleagues in the company, I'm very proud to tell others about the company that I'm working for.

The inheritance of previous studies and based on the results of expert interviews, we design, analyze and measure component attributes of the job satisfaction amongst accountants in the accounting service firms in Hanoi, thus providing some recommendations to improve the job satisfaction amongst accountants.

\section{Research Methodology}

We used a qualitative research methodology based on some in-depth interviews with 4 lecturers with proficient in accounting, auditing and consulting, both of theoretical and practical of the National Economics University and University of Labor and Social Affairs. At the same time, we interviewed 4 experts working as director, chief accountants and general accountants in accounting service firms. The results of the interviews include job satisfaction amongst accountants.

Based on the prior studies and results of qualitative research through expert interviews, we have conducted inductive method to verify, adjust and add attributes in questionnaires for collecting final data of the research.

Inheriting the results conducted by Andrew (2002), Crossman và Bassem (2003), Luddy (2005), Smith (2007), Chawla (2009), Tran (2012), Luong (2015), Do et al. (2018), Do et al. (2019b) and using qualitative research methodology through interviews with experts. We identify job satisfaction amongst accountants (JSAA) including seven attributes as follows,

\begin{tabular}{ll} 
Code & \multicolumn{1}{c}{ Variables and Its Attributes } \\
Job satisfaction amongst accountants (JSAA) \\
JSAA1 & Position and nature of work assigned \\
JSAA2 & Working conditions \\
JSAA3 & Incomes \\
JSAA4 & Welfare \\
JSAA5 & Training and promotion \\
JSAA6 & Leaders \\
JSAA7 & Colleagues \\
\hline
\end{tabular}

Then, we have designed a questionnaire consisting of 7 variables with a 5-point Likert scale from 1 "not totally satisfy" to 5 "fully satisfy". The method of data collection was accomplished through the survey and subjects were accountants doing in accounting service firms in Hanoi, belong to the type of private firm.

We sent 200 questionnaires and received the feedback of 175. After checking the information on the votes, there were 145 questionnaires with full information for data entry and analysis, the size of this sample was consistent with study of Gorsuch (1983). We used both qualitative and quantitative approaches for analysis data. SPSS is a tool to support us to have descriptive statistics, Cronbach's Alpha, Independent T-test and ANOVA were used for evaluating and measuring the job satisfaction amongst accountants in the Accounting service firms in Hanoi. 


\section{Results and Discussion}

\subsection{Descriptive Statistics}

Table 1: Personal characteristics of the participants

\begin{tabular}{|c|c|c|c|}
\hline & Frequency & Percent & Cumulative Percent \\
\hline \multicolumn{4}{|l|}{ Gender } \\
\hline Male & 33 & 22.8 & 22.8 \\
\hline Female & 112 & 77.2 & 100.0 \\
\hline \multicolumn{4}{|l|}{ Age } \\
\hline 30 to 40 & 79 & 54.5 & 54.5 \\
\hline Less 30 & 35 & 24.1 & 78.6 \\
\hline Over 40 & 31 & 21.4 & 100.0 \\
\hline Total & 145 & 100.0 & \\
\hline
\end{tabular}

Table 1 shows that among the 145 respondents, $22.8 \%$ of the participants were male while the remaining 112 were female, representing for $77.2 \%$. Of these, 79 of them $30-40$ ages, accounting for $54.5 \% ; 35(24.1 \%)$ less 30 ages and $21.4 \%$ of the participants were over 40 ages.

Table 2: Descriptive Analysis of Attributes of the job satisfaction amongst accountants

\begin{tabular}{lccccc}
\hline & $\mathrm{N}$ & Minimum & Maximum & Mean & Std. Deviation \\
\cline { 2 - 6 } & Statistic & Statistic & Statistic & Statistic & Statistic \\
JSAA1 & 145 & 1.0 & 5.0 & 3.476 & 1.014 \\
JSAA2 & 145 & 1.0 & 5.0 & 3.630 & 1.026 \\
JSAA3 & 145 & 2.0 & 5.0 & 3.520 & .875 \\
JSAA4 & 145 & 1.0 & 5.0 & 3.410 & .886 \\
JSAA5 & 145 & 1.0 & 5.0 & 3.821 & .910 \\
JSAA6 & 145 & 1.0 & 5.0 & 3.855 & .905 \\
JSAA7 & 145 & 3.0 & 5.0 & 4.069 & .732 \\
Valid N & 145 & & & $\mathbf{3 . 6 8 3}$ & \\
(listwise) & & & & &
\end{tabular}

Data in Table 2 illustrate that the respondents satisfaction with the dependent variables of "the job satisfaction amongst accountants" where seven attributes were quite high with an average of 3.683 compared with the highest of the Likert 5-point scale. All 7 attributes were rated at an average of 3.410 or higher.

\subsection{Testing Cronbach's Alpha}

The job satisfaction amongst accountants has been measured by the Cronbach's Alpha with coefficient of 0.776 . Results of testing Cronbach's alpha of attributes are presented in Table 3 as follows,

Table 3: Results of Cronbach's Alpha Testing of Attributes

\begin{tabular}{lcccc} 
& $\begin{array}{c}\text { Scale Mean if } \\
\text { Item Deleted }\end{array}$ & $\begin{array}{c}\text { Scale Variance if } \\
\text { Item Deleted }\end{array}$ & $\begin{array}{c}\text { Corrected Item- } \\
\text { Total Correlation }\end{array}$ & $\begin{array}{c}\text { Cronbach's Alpha } \\
\text { if Item Deleted }\end{array}$ \\
\cline { 2 - 5 } JSAA1 & 22.303 & 7.157 & .402 & .673 \\
JSAA2 & 22.145 & 8.514 & .343 & .729 \\
JSAA3 & 22.262 & 7.709 & .378 & .641 \\
JSAA4 & 22.372 & 7.805 & .350 & .626 \\
JSAA5 & 21.959 & 7.651 & .367 & .618 \\
JSAA6 & 21.924 & 8.334 & .329 & .680 \\
JSAA7 & 21.710 & 7.777 & .470 & .638
\end{tabular}

The results also show that attributes of the dependent variables had a Cronbach's Alpha coefficient greater than 0.6 and were less than the common Cronbach's Alpha coefficient; the correlation coefficient of all attributes was greater than 0.3 , so all the attributes of the dependent variables were statistically significant (Hoang \& Chu, 2008).

\subsection{Independent $T$-test}

Comparing the results of the evaluation of the job satisfaction amongst accountants between men and women is shown in Table 4. 


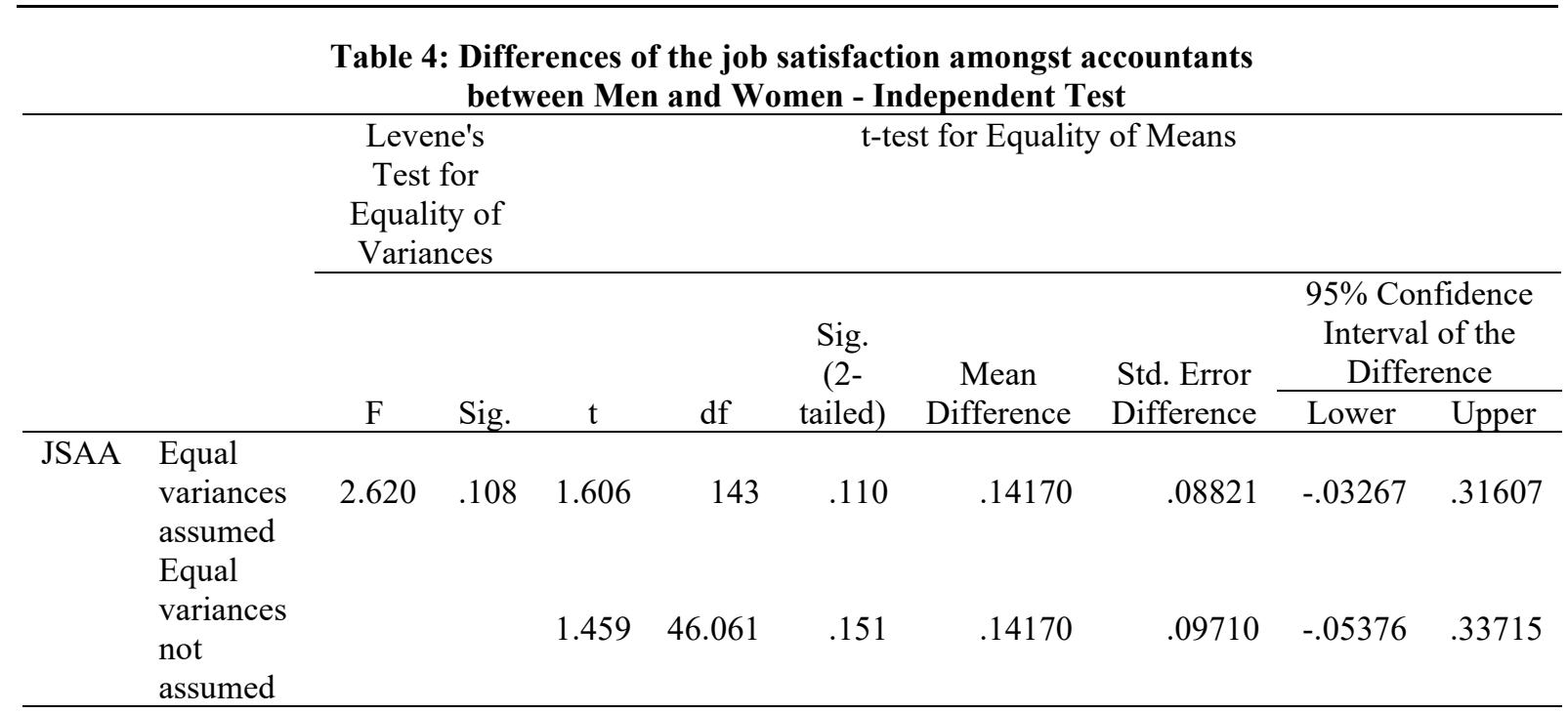

According to the results of Table 4 , Sig Levene's Test $=0.108$ more than 0.05 ; the variance between the two female and male is not different. Moreover, Sig value T-Test $=0.110>0.05$, which means there is statistically no significant difference in the level of the job satisfaction amongst accountants competence evaluation by workers who have different genders (Hoang \& Chu, 2008).

\subsection{ANOVA analysis}

ANOVA test helps us perform a comparison for the results of the evaluation of the job satisfaction amongst accountants between the three ages, including under 30 ages, from 30 to 40 ages and over 40 ages.

JSAA

Table 5: Test of Homogeneity of Variances

$\begin{array}{cccc}\text { Levene Statistic } & \text { df1 } & \text { df2 } & \text { Sig. } \\ .868 & 2 & 142 & .422\end{array}$

Table 5 shows that Sig Levene Statistic of 0.422 is more than 0.05 ; the hypothesis of homogeneity variance among the variable value groups (different ages) has not been violated.

Table 6: ANOVA

JSAA

\begin{tabular}{cccccc} 
& Sum of Squares & Df & Mean Square & F & Sig. \\
\cline { 2 - 5 } Between Groups & .054 & 2 & .027 & .133 & .875 \\
Within Groups & 28.822 & 142 & .203 & & \\
Total & 28.876 & 144 & & & \\
\hline
\end{tabular}

Table 6 shows that, Sig. $=0.875$ is more than 0.05 ; there is not statistically significant difference in the level of the job satisfaction amongst accountants for the accountant for the mentioned three groups of age (Hoang \& Chu, 2008).

Table 7: Level of job satisfaction amongst accountants

\begin{tabular}{|c|c|c|c|c|c|c|c|c|c|c|c|}
\hline \multirow[t]{2}{*}{ No } & \multirow[t]{2}{*}{ Variables and Its Attributes } & \multicolumn{2}{|c|}{$\begin{array}{c}\text { Not totally } \\
\text { satisfy }\end{array}$} & \multicolumn{2}{|c|}{$\begin{array}{c}\text { Not } \\
\text { satisfy }\end{array}$} & \multicolumn{2}{|c|}{ Satisfy } & \multicolumn{2}{|c|}{$\begin{array}{c}\text { Quite } \\
\text { satisfy }\end{array}$} & \multicolumn{2}{|c|}{$\begin{array}{c}\text { Fully } \\
\text { satisfy }\end{array}$} \\
\hline & & $\mathrm{n}$ & $\%$ & $\mathrm{n}$ & $\%$ & $\mathrm{n}$ & $\%$ & $\mathrm{n}$ & $\%$ & $\mathrm{n}$ & $\%$ \\
\hline \multirow[t]{2}{*}{1} & Position and nature of work & 7 & 4.8 & 14 & & 48 & & 55 & & 21 & \\
\hline & assigned & & & & 9.7 & & 33.1 & & 37.9 & & 14.5 \\
\hline 2 & Working conditions & 8 & 5.5 & 13 & 9.0 & 25 & 17.2 & 77 & 53.1 & 22 & 15.2 \\
\hline 3 & Incomes & 0 & 0 & 22 & 15.2 & 41 & 28.3 & 67 & 46.2 & 15 & 10.3 \\
\hline 4 & Welfare & 5 & 3.4 & 18 & 12.4 & 41 & 28.3 & 75 & 51.7 & 6 & 4.1 \\
\hline 5 & Training and promotion & 2 & 1.4 & 7 & 4.8 & 42 & 29.0 & 58 & 40.0 & 36 & 24.8 \\
\hline 6 & Leaders & 2 & 1.4 & 6 & 4.1 & 41 & 28.3 & 58 & 40.0 & 38 & 26.2 \\
\hline 7 & Colleagues & 0 & 0 & 0 & 0 & 34 & 23.4 & 67 & 46.2 & 44 & 30.3 \\
\hline
\end{tabular}

\subsection{Discussion}

\section{Position and nature of work assigned}

Table 7 shows: When being asked "Whether or not satisfied with the position and nature of the job assigned", $4.8 \%$ were very dissatisfied, $9.7 \%$ were dissatisfied and the remaining - 85.5\% - were satisfied or very satisfied.

Arrangement and assignment of work: The accounting manager performs the personnel arrangement and assigns 
work for accountants in the companies based on the actual work completed. Accountants have the opportunity to change to other jobs that are more suitable with them thanks to the policy of self-introduction, self-nomination. However, companies have not fully considered the needs of accountants about the position they are working.

Performance evaluation: Accounting service companies have step-by-step analyzed jobs for each position, each accounting section at the company, but the results have only been able to build a job description. Evaluation of work performance at accounting service companies is still inaccurate. Therefore, the fairness in evaluating the performance at accounting service companies is still limited.

\section{Working conditions}

Table 7 shows: When being asked "Whether or not satisfied with working conditions", 5.5\% were very dissatisfied, $9.0 \%$ were dissatisfied, $17.2 \%$ were satisfied and the $68.3 \%$ remaining were quite satisfied and very satisfied.

Working environment: The accounting service firms in Hanoi have developed internal rules and regulations, contributing to creating a happy and harmonious working atmosphere at the workplace, which are in accordance with specific characteristics of the accounting service industry. The policy of accounting service companies is to create a friendly working environment, to promote equality in the workplace. However, the working environment of accounting service companies still has shortcomings that need to be improved.

Facilities and equipment: Most of the accounting service firms in Hanoi rent their offices; fimrs have invested in modern equipment such as computers, printers, receipt printers, photocopiers, accounting software, etc, to minimize the time required for jobs. In addition, working rooms are equipped with air-conditioners, meeting rooms have projector system, sound system, etc. Basics personal needs of accountants are satisfied such as water, toilets. However, resting place for lunch break of the accountants is their working position. However, the accounting software used at accounting service firms is mainly purchased from other party, so it is still passive during use. The accounting service firms have not built their accounting information system, or just take the first step on building it.

Incomes

Table 7 shows: When being asked "Whether or not satisfied with incomes", 15.2\% were dissatisfied, 28.3\% were satisfied and the $56.5 \%$ remaining were quite satisfied and very satisfied.

Income from wages represents a difference between job positions and work job experience. In addition to salary over time, accountants receive a sales salary for completed service provision contracts. If an accountant introduces new customers to the company, the accountant will also receive a commission of $5 \%$ to $10 \%$ of the revenue from that customer (Do et al. 2019b).

Payment time: Firms pay monthly salaries for all employees on the days from the 3rd to 6th of the following month. The way to receive salary is by bank transfer via ATM card system of the bank (Do et al. 2019b).

\section{Welfare}

Table 7 shows: When being asked "Whether or not satisfied with the company's welfare", $15.8 \%$ were very dissatisfied and dissatisfied, $28.3 \%$ were satisfied and the $55.8 \%$ remaining were quite satisfied and very satisfied. Emulation activities: Accounting service firms have facilitated and promoted cultural activities, sports, sightseeing, vacation and exchanges. However, the organization of those events is still occasional and the activities during each event are not opulent. Specifically: annual vacation activities, year-end ceremony and anniversary of founding the company are held once a year, while other activities such as cultural and artistic exchanges, sport competitions are not organized, or organized within a short period, thus not attractive enough for accountants.

Medical examination and health care: At accounting service firms, accountants can use their annual leave to go directly to medical examination and treatment facilities. However, many companies have not organized annual medical examinations, not inviting medical staffs to come to examine the accountants, but only allow the accountants to take the day-off to go for a medical checking themselves.

\section{Training and promotion}

Table 7 shows, when being asked "Whether or not satisfied with training and promotion", $29.0 \%$ rated satisfaction, in which the number of fairly satisfied people accounted for $40.0 \%$, and the number of very satisfied people accounted for $24.8 \%$.

Professional training: Most accounting service firms in Hanoi have developed and implemented a training program for accounting human resources. Although the content of the training program has certain differences among companies, companies often have the following forms of training such as: (i) For new accountants: Retraining right after entering the company, assigning to an appropriate working groups to learn from each other. (ii). For the former accountants: Organizing short-term training in the form of company's training course or sending accountants to study classes organized by Vietnam Association of Accountants and Auditors (VAA), the Vietnam association of certified public accountants.

Promotion opportunities: The opportunities for career advancement of accountants in accounting service firms is quite good. The company's customers are diverse in various business lines, each of which has its own unique characteristics that require different accounting process handling. Some accounting service firms are based on the work performance evaluation to appoint accountants to other position such as: Head of Deputy, Head of 
Department. But in fact, accounting service companies have not have a specific document on the promotion roadmap for accountants. Moreover, the promotions are decided by the superiors, without any consultation or voting in the collective.

\section{Leaders}

Table 7 shows that, 41 out of 145 people rated satisfaction with leaders $(28.3 \%), 58$ people were quite satisfied $(40 \%)$ and 38 people were very satisfied $(26.2 \%)$.

The relationship between leaders and employees in accounting service firms always achieves openness, friendliness, attachment and willingness to help each other at work; the superiors always try to listen to get on well with their employees and support them; the junior staff always believe in the guidance of superiors.

Accountants often exchange their opinions on professional technique and income with the head of the department, the board of directors, and the board of directors seriously take opinions of accountants into consideration.

\section{Colleagues}

Table 7 shows that, 34 out of 145 people rated satisfaction with colleagues (23.4\%), 67 people were quite satisfied $(46.2 \%)$ and 44 people were very satisfied $(30.3 \%)$.

Accountants certainly do not want to work in an environment in which colleagues, superiors, subordinates are not in sync or in conflict. In contrast, the accountants will not be able to refuse to do so in a fair and respected environment which is full of professional in communication as well as work. At the same time, the accountants are very proud to tell others about the business they are working.

\section{Recommendations}

Accounting service firms should pay more attention to the work of appropriately arranging, assigning employees to promote their full potential. It is necessary to develop standards for job performance for each job position associated with the specific accounting practice. Conduct a fairer performance evaluation.

Accounting service firms need to improve a friendly working environment, thus achieve the harmony in the superior-subordinate relationships as well as in colleague relationships.

Accounting service firms need to build accounting software to be more proactive in using them. The selfbuilding accounting software contributes to the construction and completion of the accounting information system. In addition, an accounting system built should combine both financial accounting and management accounting.

Accounting service firms need to pay more attention to health care and physical activities of accountants. Emulation activities should be organized more often, the annual gala meeting of the whole family of employees should also be held once a year.

\section{Refereces}

1. Andrew, O. (2002). Are You Happy at Work? Job Satisfaction and Work-Life Balance in the US and Europe Warwick WBS Event 5, New York.

2 Chawla, P. (2009), "Job satisfaction of call center employees", International Research Journal, Vol.2, Issue 7.

3. Crossman A. \& Bassem Abou-Zaki (2003), "Job satisfaction and employee performance of Lebanese banking staff”, Journal of Managerial Psychology, 18(4), 368-376.

4. Do, D.T, Truong, D.D, Tran, M.D \& Nguyen,T.N.L., (2018). Determinants Influencing Performance of Accountants: The Case of Vietnam, International Journal of Economics and Finance; Vol. 10, No. 7; 2018, $1-9$.

5. Do, D.T., Tran, B.M., Nguyen, T.N.L., Truong, D.D., \& Tran, M.D., (2019a), Determinants influencing the quality of accounting human resources: The case of Hanoi, Vietnam, $10^{\text {th }}$ International conference socio economic and environmental issues in development, 2019, 711-726.

6. Do, D.T, Ha, S.T, Tran, M.D, \& Nguyen, T.T., (2019b). Motivation for accounting human resources by material stimulation: The case of accounting service firms in Hanoi, Vietnam, Accounting 6 (2020), 23-32.

7. Gorsuch, R. L. (1983), Factor Analysis $2^{\text {nd }}$ Ed.., Hillsdale, NJ: Erlbaum.

8. Hoang, T., \& Chu, N.M.N (2008). Analysis of research data with SPSS. Hong Duc Publishing House.

9. Le, T.P., (2016), The role of employees commitment and their job satisfaction for the strategy execution in firm, Journal of Trade Science, No 93/2016, 50-57.

10. Luddy, N. (2005). Job satisfaction amongst employees at a public Health Institution in the Western Cape, University of the Western Cape.

11. Luong, T.T., (2015). The job satisfaction of workers in SOS Children's Village in Northern Vietnam, Master thesis, University of Labor and Social Affairs, Vietnam.

12. Smith, T.W. (2007). Job satisfaction in Ihe United States. University of Chicago. 